\title{
Heterogeneous biocatalysis in the generation of thrombin
}

Citation for published version (APA):

Hemker, H. C., \& Zwaal, R. F. A. (1982). Heterogeneous biocatalysis in the generation of thrombin. Trends in Biochemical Sciences, 7(10), 378-381. https://doi.org/10.1016/0968-0004(82)90120-7

Document status and date:

Published: 01/10/1982

DOI:

10.1016/0968-0004(82)90120-7

Document Version:

Other version

\section{Please check the document version of this publication:}

- A submitted manuscript is the version of the article upon submission and before peer-review. There can be important differences between the submitted version and the official published version of record.

People interested in the research are advised to contact the author for the final version of the publication, or visit the DOI to the publisher's website.

- The final author version and the galley proof are versions of the publication after peer review.

- The final published version features the final layout of the paper including the volume, issue and page numbers.

Link to publication

\footnotetext{
General rights rights.

- You may freely distribute the URL identifying the publication in the public portal. please follow below link for the End User Agreement:

www.umlib.nl/taverne-license

Take down policy

If you believe that this document breaches copyright please contact us at:

repository@maastrichtuniversity.nl

providing details and we will investigate your claim.
}

Copyright and moral rights for the publications made accessible in the public portal are retained by the authors and/or other copyright owners and it is a condition of accessing publications that users recognise and abide by the legal requirements associated with these

- Users may download and print one copy of any publication from the public portal for the purpose of private study or research.

- You may not further distribute the material or use it for any profit-making activity or commercial gain

If the publication is distributed under the terms of Article $25 \mathrm{fa}$ of the Dutch Copyright Act, indicated by the "Taverne" license above, 


\section{Heterogeneous biocatalysis in the generation of thrombin}

\author{
H. C. Hemker and R. F. A. Zwaal
}

The sequence of conversions of proenzyme into enzyme, which leads to the formation of thrombin in blood as soon as it leaves normal circulation, has recently been subject to extensive investigation. The plasma proteins involved in this process have been purified and the primary structure of most of them is known.

The sequence of proteolytical cleavages that eventually forms thrombin is well documented (for reviews, see Refs 1,2). We will discuss a peculiar feature of the blood coagulation reaction sequence, viz. the occurrence of proteolytic enzymes in a complex with phospholipids and an 'accessory protein' which allows the enzymes to act with much increased efficiency

The activation of prothrombin may serve as a first example. Prothrombin (see Fig. 1) is a $72,500 \mathrm{~mol}$. wt protein, the $\mathrm{C}$-terminal part of which yields thrombin when cleaved at two different sites. This cleavage is brought about by a serine protease called activated factor $X\left(\mathrm{~F} \cdot \mathrm{X}_{\mathrm{a}}\right)$. The velocity of this reaction can be enhanced up to 100,000 -fold by the addition of a plasma protein called factor $V_{\mathrm{a}}$ and a suitable phospholipid surface. Factor $\mathrm{X}_{\mathrm{a}}$ and factor $V_{a}$ adsorb at the phospholipid-water interface to form a complex which converts prothrombin (F.II) into thrombin (Fig. 2a). A second example concerns the activation of factor $\mathrm{X}$. The unactivated factor $\mathrm{X}$ which occurs as a proenzyme in plasma, is converted into an active protease by a complex consisting of the protease factor IX together with the accessory protein factor VIII adsorbed at a phospholipid surface (Fig. 2b).

We investigated the mechanisms by which the phospholipids and the accessory protein, neither of which have any enzymatic action by themselves, influence the activity of the proteolytic enzymes. It is not our intention to give a complete review of blood coagulation biochemistry and consequently several important items will not be discussed such as:

(i) the way in which factor IX is activated;

(ii) the activation of factor $\mathrm{X}$ by tissue thromboplastin and factor $\mathrm{VII}_{a}$;

(iii) the fact that the accessory proteins (F.V., F.VIII) have to be activated by thrombin in order to be able to participate in the reaction.

We will focus our attention to the two complexes shown in Fig. 2, not only because they can serve as good examples of heterogeneous biocatalysis but also because they show a mechanism that may be of much more general importance than in the coagulation of blood alone.

Two relatively recent developments made it possible to study these complexes in some detail: first, it is possible to purify the blood coagulation factors, giving preparations that contain no detectable contaminants as judged by physical, chemical or functional analyses ${ }^{3}$. Elementary though this may seem, most of the early research was carried out with impure preparations. The coagulation factors II, VII, IX and X have extensive homologies and copurify under a large variety of conditions. A second major step forward was the introduction of chromogenic substrates. These are tri- or tetrapeptides, usually blocked at the $\mathrm{N}$-terminal end and linked to a $p$-nitroanilide group at the $\mathrm{C}$-terminal. Specific combinations of amino acids make them especially vulnerable to certain serine amidases that arise during blood coagulation. For example, H-D-Phe-Pip-Arg-pNA e.g. is specifically split by thrombin (F.IIa) whereas Bz-Ile-Glu-Gly-Arg-pNA is specific for activated factor X (F.Xa) (Refs $4,5)$.

With purified clotting factors and chromogenic substrates the experimental set up sketched out in Fig. 3 made it possible to investigate four details of the reaction $^{4.5 .9}$.

(a) By varying the components of the enzyme complex the stoichiometry of enzyme (i.e. factor IX $\mathrm{X}_{\mathrm{a}}$ or factor $\mathrm{X}_{\mathrm{a}}$ ), accessory protein (i.e. factor $\mathrm{VIII}_{\mathrm{a}}$ or factor $V_{a}$ ) and phospholipid surface could be determined.

(b) By varying the substrate concentration, the $K_{\mathrm{m}}$ and $k_{\text {cat }}$ of the activating enzyme complex in its different forms could be determined.

(c) By varying the phospholipid composition, the optimal phospholipid requirement for the interaction could be investigated.

(d) By substituting blood platelets (thrombocytes) for phospholipids, it was possible to discover the conditions

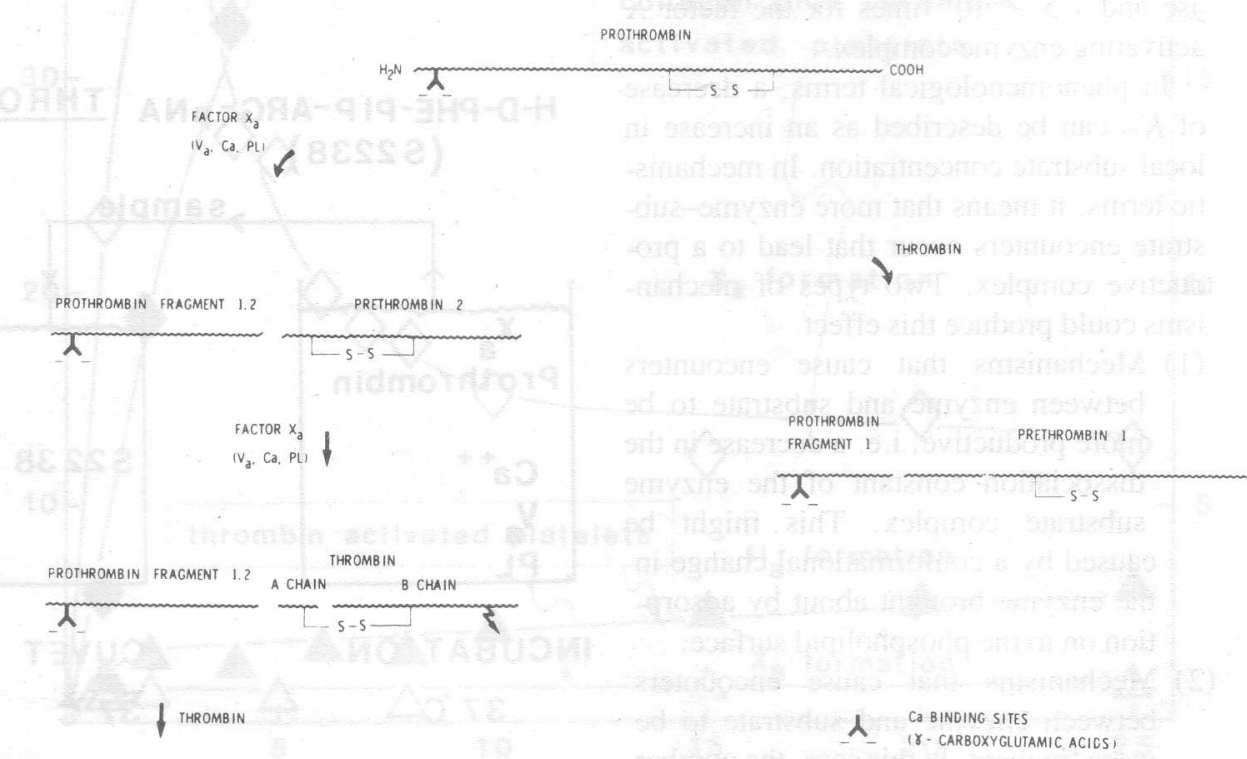

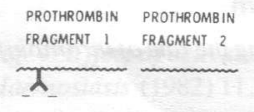

Fig. 1. Proteolytic activation of prothrombin. 
under which these cells make procoagulant phospholipids.

We will discuss the results in terms of prothrombinase and only divert our attention to the factor X-activating enzyme where this shows special features. In general, the results hold mutatis mutandis for both enzyme complexes (see Table I).

Factor $\mathrm{X}_{\mathrm{a}}$ in free solution (that is in the absence of phospholipids) can activate prothrombin by its own, but only very slowly. Addition of factor $V_{a}$ causes an increase in the turnover number of this reaction but does not influence the $K_{\mathrm{m}}$ to any appreciable extent. Factor $V_{\mathrm{a}}$ and Factor $\mathrm{X}_{\mathrm{a}}$ form a $1: 1$ stoichiometric complex with a dissociation constant of $3 \times 10^{-4} \mathrm{M}$. When, on the other hand, only phospholipids are added to factor $X_{a}$ (that is in the absence of factor $V_{a}$ ) the turnover number of prothrombin activation hardly changes, but the $K_{\mathrm{m}}$ drops markedly. For this to occur it is necessary that both the enzyme and the substrate bind to the phospholipid surface. This binding is mediated by $\gamma$-carboxy glutamic acid residues in the $\mathrm{N}$-terminal part of both proteins. These residues are produced from normal glutamic acid residues by vitamin $\mathrm{K}$-dependent carboxylation. In vitamin $\mathrm{K}$. deficiency this carboxylation does not take place and uncarboxylated clotting factors can be isolated from the plasma. These molecules are perfectly capable of forming normal active sites upon activation but they do not bind to phospholipids and therefore can be used to investigate the importance of this binding $5,7,8$.

When factor $V_{a}$ and phospholipid are both present, $k$ cat increases with a concomitant decrease in $K \mathrm{~m}$. In this way the catalytic efficiency of the reaction can be increased up to $10^{5}$ times for prothrombinase and $1.5 \times 10^{7}$ times for the factor $\mathrm{X}$ activating enzyme complex.

In phenomenological terms, a decrease of $K_{\mathrm{m}}$ can be described as an increase in local substrate concentration. In mechanistic terms, it means that more enzyme-substrate encounters occur that lead to a productive complex. Two types of mechanisms could produce this effect.

(1) Mechanisms that cause encounters between enzyme and substrate to be more productive, i.e. a decrease in the dissociation constant of the enzyme substrate complex. This might be caused by a conformational change in the enzyme brought about by adsorption on to the phospholipid surface.

(2) Mechanisms that cause encounters between enzyme and substrate to be more frequent. In this case, the number of productive encounters could increase either because of the high local concentration of both molecules
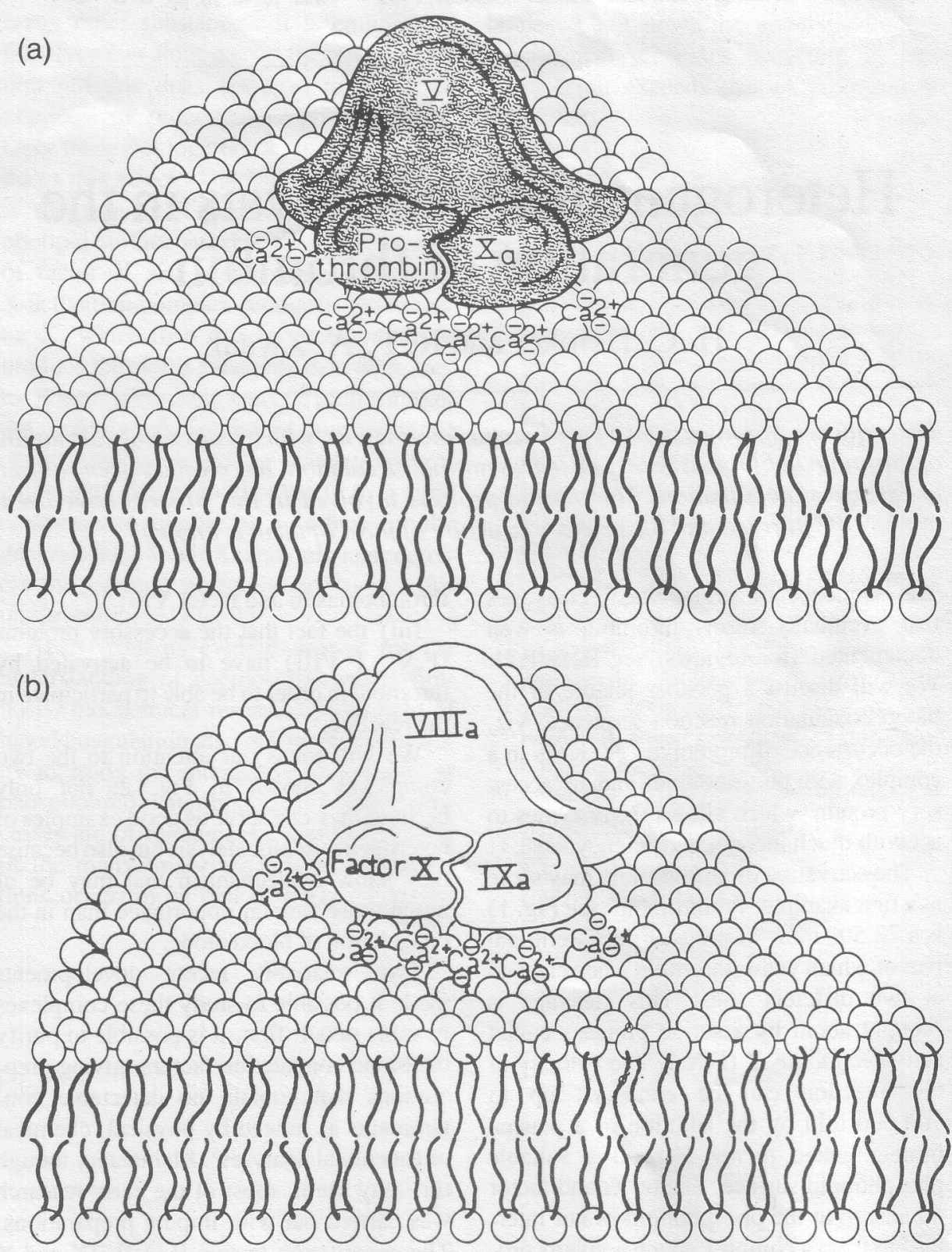

Fig. 2. Prothrombinase and the factor $X$ activating complex.

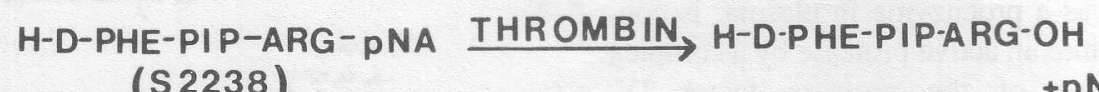
(S2238)

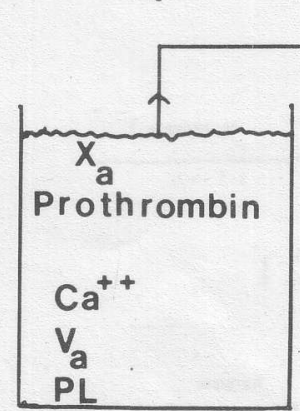

INCUBATION

$37^{\circ} \mathrm{C}$ sample

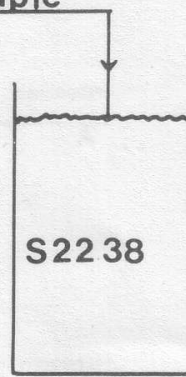

CUVET

$37^{\circ} \mathrm{C}$
+ pNA

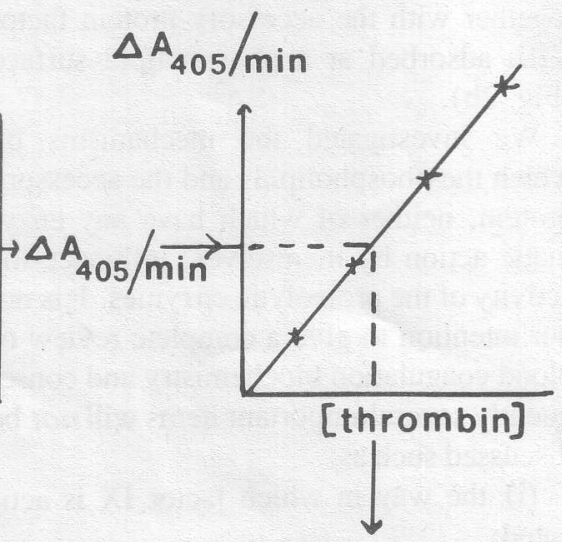

rate of thrombin formation

Fig. 3. Method for measuring the rate of thrombinformation. (The rate of Factor X activation is measured in an analogous set up.) 
TABLE 1.

Kinetic parameters of prothrombin and factor $\mathrm{X}$ activation ${ }^{4.5}$

\begin{tabular}{|c|c|c|}
\hline Prothrombin activator & $K \mathrm{~m}(\mu \mathrm{M})$ & $V_{\max }\left(\mu \mathrm{mol} \mathrm{IIA}_{\mathrm{min}}{ }^{-1} \mu\right.$ mole $\left.\mathrm{XA}_{\mathrm{A}}\right)$ \\
\hline $\mathrm{Xa}, \mathrm{Ca}^{2}$ & $84=$ & 0.68 \\
\hline $\mathrm{Xa}, \mathrm{Ca}^{2}, \mathrm{PL}(7.5 \mu \mathrm{M})$ & 0.06 & 2.3 \\
\hline $\mathrm{X}_{\mathrm{a}}, \mathrm{Ca}^{2-}, \mathrm{PL}(7.5 \mu \mathrm{M}), \mathrm{VA}$ & 0.21 & 1919 \\
\hline Facor $X$ activator & $K \mathrm{~m}(\mu \mathrm{M})$ & $V \max \left(\mu \operatorname{mol} X_{A} \min ^{-1} \mu\right.$ mole $\left.\mathrm{IXA}^{-1}\right)$ \\
\hline $\mathrm{IXA}, \mathrm{Ca}^{2}$ & 181 & 0.01 \\
\hline $\mathrm{IXA}, \mathrm{Ca}^{2}, \mathrm{PL}(10 \mu \mathrm{M})$ & 0.06 & 0.0025 \\
\hline IXA, Ca ${ }^{2}$, PL $(10 \mu \mathrm{M})$ VIIIA & 0.063 & 500 \\
\hline
\end{tabular}

at the lipid surface (assuming a sufficient lateral mobility of the molecules) and/or because of a higher number of sterically favourable encounters when the molecules become oriented at the surface.

At the moment, no clearcut decision between these models can be made, although calculations of $k \mathrm{cat} / K_{\mathrm{m}}$ in the first model lead to numbers as high as $3.3 \times 10^{5}$ $\mathrm{s}^{-1} \mathrm{M}^{-1}$ which would indicate a catalytic efficiency higher than other serine proteases and equal to the most efficient enzyme known (i.e. crotonase, $2.8 \times 10^{8}$ $\left.\mathrm{s}^{-1} \mathrm{M}^{-1}\right)$. In the second model, $k \mathrm{cat} / K \mathrm{~m}$ of the surface bound species would be about $4.6 \times 10^{2} \mathrm{~s}^{-1} \mathrm{M}^{-1}$ which seems more realistic.

Two interesting observations shed some light upon the possible action of factor $\mathrm{V}_{\mathrm{a}}$ in increasing $k_{\text {cat. }}$ First, in the absence of factor $\mathrm{V}_{\mathrm{a}}$, only the first cleavage of prothrombin takes place (see Fig. 1). The intermediate product, that is one chain inactive thrombin (prethrombin 2), is dissociated from the enzyme. In the presence of factor $\mathrm{V}_{\mathrm{a}}$ however, prethrombin 2 is cleaved immediately after its formation and two chain thrombin is the only product found under these conditions ${ }^{4}$. Secondly, the chromogenic substrate split by factor $\mathrm{X}_{\mathrm{a}}$ competitively inhibits the conversion of factor II because it occupies the active site of factor $\mathrm{X}_{\mathrm{a}}$, as would be expected. In the absence of factor $V_{a}$ however, prothrombin at concentrations as high as $10 \times K \mathrm{~m}$, quite unexpectedly does not inhibit the conversion of the small molecular weight substrate. At this substrate concentration, more than $90 \%$ of the enzyme is bound to prothrombin, yet it appears that the large majority of its active sites are free. We therefore surmise that factor $\mathrm{V}_{\mathrm{a}}$ orients the vulnerable sites of the large molecular substrate to the active sites of the activating enzyme, and keeps the intermediate product near the enzyme so that its second vulnerable site is cleaved immediately after the first.

Investigations of the effect of the phospholipid composition on the reaction confirmed the well-known observations that a net negative charge of the phospholipids is a prerequisite for their activity. It also appears that the phospholipids must be above their transition temperature to act as procoagulants. This was found by comparing mixed vesicles of synthetic phosphatidylserine (PS) and phosphatidylcholine (PC) with different fatty acid compositions. The activity of the mixtures below their transition point could be markedly enhanced by adding cholesterol ${ }^{9}$, a procedure which induces a more fluid state of the bilayer.

Why membrane fluidity is important cannot yet be explained with certainty. It can be argued, however, that the lateral mobility of proteins bound to fluid lipid surfaces will be much higher than proteins bound to lipids in the gel state. At least one of the models proposed to explain the action of phospholipids (no. 2) requires lateral

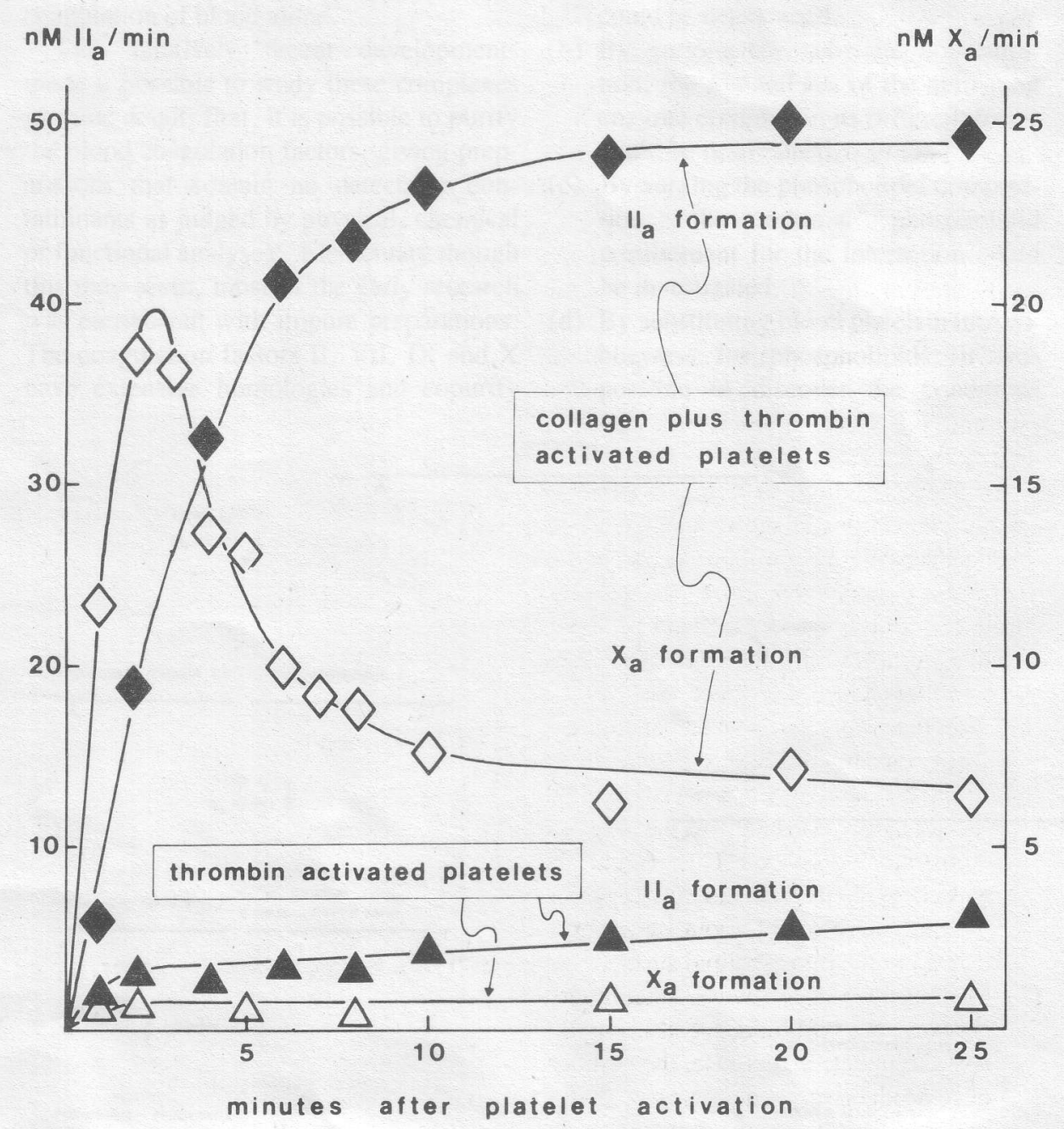

Fig. 4. Effect of activated platelets on prothrombin and factor $X$ activation. (Taken from Zwaal and Hemker,

Haemostasis (1982) 11, 12-39.) mobility in the plane of adsorption. Another possibility is that sufficient fluidity is a necessary condition for the binding of factor $V_{a}$

It is known that mixtures of phospholipids act better in coagulation than pure phospholipids. This was also confirmed with the system described above. It is interesting to note, however, that the optimal ratio of $\mathrm{PS}$ to $\mathrm{PC}$ is different for the complete prothrombinase complex as compared to the factor $\mathrm{X}$ activating complex. This is especially important in the light of the results obtained when blood platelets are used as a source of phospholipid

Zwaal and co-workers ${ }^{10}$ showed that phospholipids are asymmetrivally distributed between the inner and the outer leaflets of platelet and red cell plasma membranes. This explains why the inner face is strongly procoagulant and the outside is not and, therefore, ruptured cells increase procoagulant activity. To our surprise, however, we could show that platelets, unlike other cells, can be triggered to make procoagulant phospholipids available without rupture of the cell. This means that the intact cell can present part of its inner membrane face to the outside, and suggests a flip-flop mechanism exchanging the inner 
leaflet phospholipids for those in the outer leaflet This was demonstrated by the occurrence of procoagulant activity and by analysis of the phospholipids present in the outer leaflet after activation of the platelet $^{11}$.

The trigger to induce this behaviour is the simultaneous presence of a small amount of thrombin and collagen. These are precisely the conditions present at the site of an injury. The collagen beneath the normal endothelial cells becomes exposed and the tissue thromboplastin released by wounded cells (of almost any type) will rapidly lead to the formation of small amounts of thrombin by a pathway not discussed here. In this way, platelets adhering at the site of an injury become powerful sources of thrombin-forming activity. The consequence of this haemostatic mechanism is self evident but this process presumably also plays a role in thrombus formation that might occur at atherosclerotic lesions.

The presentation of phospholipids by the intact triggered blood platelet should not be confused with the so-called "platelet release reaction' as it indeed repeatedly has been. In this reaction, the platelet secretes ADP, serotonin, coagulation factor $\mathrm{V}, \mathrm{Ca}^{2-}$ and many other substances. It is emphasized that thrombin alone causes the release reaction but this does not lead to increased exposure of procoagulant phospholipids. Only thrombin together with collagen produces this effect. Another point of interest is the sequential generation of a phospholipid surface suitable for the activation of factor $\mathrm{X}$ and prothrombin. As factor $\mathrm{X}$-activating complex produces active factor $\mathrm{X}$, which then acts on prothrombin to produce the clotting enzyme thrombin, factor $\mathrm{X}$ activation must precede prothrombinase activity. It is indeed surprising to observe that activation of platelets by collagen plus thrombin first leads to a lipid composition suitable as a surface for the generation of factor $\mathrm{X}_{\mathrm{a}}$ and only later delivers the optimal phospholipid surface for prothrombinase (Fig. 4).

Apart from its evident interest for the understanding of haemostasis and thrombosis, biochemical research in the field of blood coagulation also offers the opportunity to study the interaction of proteins at phospholipid-water boundaries. These processes are of fundamental interest because of the many important biochemical reactions occurring at cell or organelle mem- branes. Until now, the understanding of biochemical processes occurring in free solution far exceeds that of processes at interfaces.

\section{References}

1 Suttie. J. W. and Jackson. C. M. (1977) Physiol Rev. 57 (1), 1-70

2 Jackson. C. M. and Nemerson. Y. (1980) Annu. Rev. Biochem. 49, 765-811

3 Lottenberg, R., Christensen, U., Jackson. C. M. and Coleman, P. L. Meth. Enzymol. 80 (in press)

4 Rosing, J., Tans, G., Govers-Riemslag. J. W. P.. Zwaal, R. F. A. and Hemker, H. C. (1980) J. Biol. Chem. 255, 274-283

5 v. Dieijen, G., Tans, G., Rosing. J, and Hemker, H. C. (1981) J. Biol. (hem. 256, 3433-3442

6 Josso, F., Lavergne, J. M., Gorault. M., ProuWartelle, O. and Soulier, J. P. (1968) Thromb Diathes. Haemorrh. 20, 88-89

7 Ganrot. P. O. and Nilehn. J. E. (1968) Scand. J. (lin. Lab. Inv. 22, 23-28

8 Reekers, P. P. M., Lindhout, M. J., KopKlassen, B. H. M. and Hemker, H. C. (1973) Biochim. Biophys. Acta 317, 559-562

9 Tans, G.. v. Zutphen, H. Comfurius, P. Hemker, H. C. and Zwaal, R. F. A. (1979) Eur. J. Biochem. 45, 449-457

10 Zwaal, R. F. A. (1978) Biochim. Biophys. Acta $515,163-205$

II Bevers, E. M., Comfurius, P.. v. Rijn. J. L. M. L., Hemker, H. C. and Zwaal, R. F. A (1982) Eur. J. Biochem. 122, 429-436 